\title{
Screening of Tree Species for Dendro Biomass Utility through Biometric Characterization
}

\author{
M. Thirumurugan*, K.T. Parthiban, S. Umesh Kanna and R. Thirunirai Selvan \\ Forest College and research institute, Tamil Nadu Agricultural University, \\ Mettupalayam - 641 301, Tamil Nadu, India \\ *Corresponding author
}

\section{A B S T R A C T}

\begin{tabular}{|l|}
\hline Ke y w o r d s \\
$\begin{array}{l}\text { Shoot length, Basal } \\
\text { diameter, Volume } \\
\text { index, Biometric } \\
\text { attributes, Fuel wood } \\
\text { tree species }\end{array}$ \\
\hline Article Info \\
\hline $\begin{array}{l}\text { Accepted: } \\
\text { 07 January } 2018 \\
\text { Available Online: } \\
\text { 10 February } 2018\end{array}$ \\
\hline
\end{tabular}

Keywords

Shoot length, Basal index, Biometric attributes, Fuel wood

\section{Introduction}

Fossil fuel, a non-renewable resource, highly utilized for energy generation is quite challenging option for ecological balance and environmental stability nowadays. To address this issue, choosing woody biomass based power generation provides indirect benefits which may be climatic or protective. Wood fuel provides $40 \%$ of today's global renewable energy supply as much as solar, hydro-electric and wind power combined. In India, biomass fuel is highly utilized by the rural people accounting for over 80 percent of total energy consumed. In 2011, the total annual consumption of fuelwood for the country is estimated to be 216.42 million tones out of which 58.75 million tones comes from forests. Bioenergy is expected to play an important role in future energy systems due to nature of renewable energy source that could be sustainably developed in the future and it is $\mathrm{CO}_{2}$ neutral. It provides a safe and secure energy supply that could have efficient economic potential while considering fossil fuels (Tonn, 2002). So, preliminary evaluation of fifteen fuelwood tree species is a supporting and a step forward process to identify the amenable source for biomass-based power generation. Selection of fast growing tree 
species with short rotation is the main objective of this study for the continuous supply of raw materials to the bioenergy based industries.

\section{Materials and Methods}

\section{Field experiment}

The experiment was conducted under field conditions in Randomized Block Deign (RBD) and biometric attributes viz., shoot length, basal diameter and volume index were recorded. The species under evaluation are Acacia auriculiformis, Acrocarpus fraxinifolius, Cassia siamea, TNAU Casuarina MTP 2, Casuarina junghuhniana, Chukrasia tabularis, Dalbergia sissoo, Eucalyptus camaldulensis, Gliricidia sepium, Khaya senegalensis, Leucaena leucocephala, Melia dubia, Populus deltoides, Prosopis juliflora and Thornless Prosopis. The biometric observations were recorded at 0.5 MAP, 2 MAP, 4 MAP and 6 MAP at twenty-five seedlings per replication. The data collected from various growth periods were analyzed for mean, variance and standard error were worked out using the method described by Panse and Sukhatme (1978). The significance test was carried out by referring to the standard ' $F$ ' table of Snedecor (1961).

\section{Results and Discussion}

\section{Shoot length}

Significant variations were found among different species for shoot length. At 2 Months after Planting (MAP), shoot length ranged from $27.21 \mathrm{~cm}$ (Gliricidia sepium) to 227.91 $\mathrm{cm}$ (Eucalyptus camaldulensis). Three species viz., Eucalyptus camaldulensis (227.91 cm), Casuarina junghuhniana $(223.49 \mathrm{~cm})$ and Dalbergia sissoo $(139.52 \mathrm{~cm})$ recorded significantly higher shoot length compared to general mean $(98.93 \mathrm{~cm})$.
At 4 MAP, shoot length ranged from $58.09 \mathrm{~cm}$ (Gliricidia sepium) to $238.31 \mathrm{~cm}$ (Casuarina junghuhniana). At this stage, the following three species viz., Casuarina junghuhniana $(238.31 \mathrm{~cm})$, Eucalyptus camaldulensis $(235.82 \mathrm{~cm})$ and Dalbergia sissoo $(199.75 \mathrm{~cm})$ recorded significantly higher shoot length compared to grand mean $(134.36 \mathrm{~cm})$. At 6 MAP, it ranged between $86.89 \mathrm{~cm}$ (Chukrasia tabularis) and 291.01 (Eucalyptus camaldulens). Among 15 species Eucalyptus camaldulensis (291.01), Dalbergia sissoo (278.12 cm), Casuarina junghuhniana (277.45 $\mathrm{cm})$ and Cassia siamea $(231.73 \mathrm{~cm})$ were proved superior compared to grand mean $(177.15 \mathrm{~cm})$ (Table 1).

\section{Basal diameter}

Basal diameter differed significantly among the evaluated species at four growth periods. At 2 MAP, basal diameter ranged between $2.15 \mathrm{~cm}$ (Eucalyptus camaldulensis) and 0.76 $\mathrm{cm}$ (Thornless Prosopis). Three species Eucalyptus camaldulensis $(2.15 \mathrm{~cm})$, Cassia siamea $(1.89 \mathrm{~cm})$ and Casuarina junghuhniana $(1.74 \mathrm{~cm})$ recorded significantly higher value than the grand mean $(1.24 \mathrm{~cm})$. At 4 MAP, basal diameter ranged between $2.78 \mathrm{~cm}$ (dEucalyptus camaldulensis) and 0.93 $\mathrm{cm}$ (Thornless Prosopis). Compared to mean basal diameter $(1.68 \mathrm{~cm})$, five species viz., Eucalyptus camaldulensis $(2.78 \mathrm{~cm})$, Cassia siamea $(2.58 \mathrm{~cm})$, Casuarina junghuhniana $(2.43 \mathrm{~cm})$, Acrocarpus fraxinifolius $(2.08 \mathrm{~cm})$ and Dalbergia sissoo $(1.98 \mathrm{~cm})$ registered significantly higher.

At 6 MAP, significantly higher value for basal diameter was recorded by five species which includes Cassia siamea $(3.16 \mathrm{~cm})$, Eucalyptus camaldulensis $(3.14 \mathrm{~cm}), \quad$ Casuarina junghuhniana $(2.88 \mathrm{~cm})$, Dalbergia sissoo $(2.72 \mathrm{~cm})$ and Acrocarpus fraxinifolius $(2.51$ $\mathrm{cm})$ compared to grand mean $(2.13 \mathrm{~cm})$ (Table 2). 
Table.1 Shoot length of various species at different growth periods

\begin{tabular}{|c|c|c|c|c|}
\hline \multirow[t]{2}{*}{ Treatments / species } & \multicolumn{4}{|c|}{ Shoot length (cm) } \\
\hline & 0.5 MAP & 2 MAP & 4 MAP & 6 MAP \\
\hline Acacia auriculiformis & 38.05 & 78.45 & 132.98 & 143.34 \\
\hline Acrocarpus fraxinifolius & 28.36 & 58.25 & 126.01 & 145.02 \\
\hline Cassia siamea & 25.85 & 91.95 & 161.43 & $231.73^{*}$ \\
\hline TNAU Casuarina MTP 2 & $86.68 *$ & 105.75 & 130.21 & 185.88 \\
\hline Casuarina junghuhniana & $125.46^{*}$ & $223.49 *$ & $238.31 *$ & $277.45^{*}$ \\
\hline Chukrasia tabularis & 47.79 & 66.43 & 83.43 & 86.89 \\
\hline Dalbergia sissoo & 36.65 & $139.52 *$ & $199.75^{*}$ & $278.12 *$ \\
\hline Eucalyptus camaldulensis & $119.51^{*}$ & $227.91^{*}$ & $235.82 *$ & $291.01 *$ \\
\hline Gliricidia sepium & 12.76 & 27.21 & 58.09 & 120.02 \\
\hline Khaya senegalensis & 38.65 & 47.40 & 69.62 & 110.16 \\
\hline Leucaena leucocephala & $84.03 *$ & 107.88 & 141.91 & 192.91 \\
\hline Melia dubia & 23.84 & 62.53 & 116.50 & 171.63 \\
\hline Populus deltoides & 12.08 & 46.79 & 94.25 & 169.08 \\
\hline Prosopis juliflora & $94.30 *$ & 89.24 & 112.57 & 138.62 \\
\hline Thornless Prosopis & $108.76^{*}$ & 111.22 & 114.58 & 115.45 \\
\hline Mean & 58.85 & 98.93 & 134.36 & 177.15 \\
\hline SEd & 2.79 & 10.06 & 19.67 & 21.08 \\
\hline $\mathrm{CD}(0.05)$ & 5.64 & 20.30 & 39.70 & 42.54 \\
\hline
\end{tabular}

*Significant at $5 \%$ level.

Table.2 Basal diameter of various species at different growth periods

\begin{tabular}{|l|l|l|l|l|}
\hline Treatments / species & \multicolumn{5}{|c}{ Basal diameter (cm) } \\
\hline Acacia auriculiformis & $\mathbf{0 . 5}$ MAP & 2 MAP & 4 MAP & 6 MAP \\
\hline Acrocarpus fraxinifolius & 0.35 & 1.04 & 1.19 & 1.80 \\
\hline Cassia siamea & 0.34 & 1.39 & $2.08^{*}$ & $2.51^{*}$ \\
\hline TNAU Casuarina MTP 2 & 0.53 & $1.89^{*}$ & $2.58^{*}$ & $3.16^{*}$ \\
\hline Casuarina junghuhniana & 0.67 & 1.04 & 1.45 & 1.83 \\
\hline Chukrasia tabularis & $0.78^{*}$ & $1.74^{*}$ & $2.43^{*}$ & $2.88^{*}$ \\
\hline Dalbergia sissoo & 0.26 & 0.80 & 0.99 & 1.30 \\
\hline Eucalyptus camaldulensis & 0.27 & 1.34 & $1.98^{*}$ & $2.72^{*}$ \\
\hline Gliricidia sepium & $0.83^{*}$ & $2.15^{*}$ & $2.78^{*}$ & $3.14^{*}$ \\
\hline Khaya senegalensis & $0.90^{*}$ & 1.34 & 1.68 & 2.14 \\
\hline Leucaena leucocephala & 0.52 & 1.09 & 1.53 & 2.26 \\
\hline Melia dubia & 0.48 & 0.95 & 1.40 & 1.71 \\
\hline Populus deltoides & 0.46 & 1.26 & 1.70 & 2.05 \\
\hline Prosopis juliflora & $0.79^{*}$ & 0.83 & 1.25 & 1.93 \\
\hline Thornless Prosopis & 0.62 & 1.02 & 1.27 & 1.48 \\
\hline Mean & 0.67 & 0.76 & 0.93 & 0.99 \\
\hline SEd & $\mathbf{0 . 5 6}$ & $\mathbf{1 . 2 4}$ & $\mathbf{1 . 6 8}$ & $\mathbf{2 . 1 3}$ \\
\hline CD (0.05) & 0.04 & 0.11 & 0.14 & 0.18 \\
\hline Signficant at & 0.08 & 0.23 & 0.28 & 0.37 \\
\hline
\end{tabular}

*Significant at $5 \%$ level. 
Table.3 Volume index of various species at different observation periods

\begin{tabular}{|c|c|c|c|c|}
\hline \multirow[t]{2}{*}{ Treatments / species } & \multicolumn{4}{|c|}{ Volume index $\left(\mathrm{cm}^{3}\right)$} \\
\hline & 0.5 MAP & 2 MAP & 4 MAP & 6 MAP \\
\hline Acacia auriculiformis & 4.75 & 85.43 & 190.05 & 469.02 \\
\hline Acrocarpus fraxinifolius & 3.27 & 115.28 & 549.16 & 916.06 \\
\hline Cassia siamea & 7.25 & $327.87^{*}$ & 1091.46* & $2353.72 *$ \\
\hline TNAU Casuarina MTP 2 & $38.71^{*}$ & 132.06 & 326.35 & 643.64 \\
\hline Casuarina junghuhniana & $76.87^{*}$ & $682.75^{*}$ & $1424.85^{*}$ & $2318.06^{*}$ \\
\hline Chukrasia tabularis & 3.27 & 42.40 & 81.71 & 147.69 \\
\hline Dalbergia sissoo & 2.72 & 276.58 & $860.98^{*}$ & $2305.53 *$ \\
\hline Eucalyptus camaldulensis & $81.86^{*}$ & $1052.62^{*}$ & $1838.42 *$ & $2865.34^{*}$ \\
\hline Gliricidia sepium & 11.13 & 49.49 & 162.18 & 564.09 \\
\hline Khaya senegalensis & $10.38^{*}$ & 56.63 & 165.25 & 573.71 \\
\hline Leucaena leucocephala & 19.67 & 99.13 & 286.73 & 564.55 \\
\hline Melia dubia & 5.22 & 116.60 & 355.99 & 728.95 \\
\hline Populus deltoides & 7.58 & 34.93 & 146.26 & 765.37 \\
\hline Prosopis juliflora & $36.76^{*}$ & 94.80 & 184.84 & 313.51 \\
\hline Thornless prosopis & $48.33^{*}$ & 63.84 & 99.10 & 113.21 \\
\hline Mean & 23.85 & 215.36 & 517.56 & 1042.83 \\
\hline SEd & 3.00 & 50.24 & 176.71 & 320.02 \\
\hline $\mathrm{CD}(0.05)$ & 6.05 & 101.42 & 356.69 & 645.97 \\
\hline
\end{tabular}

*Significant at $5 \%$ level.

Fig.1 Volume index of different tree species at 6 MAP

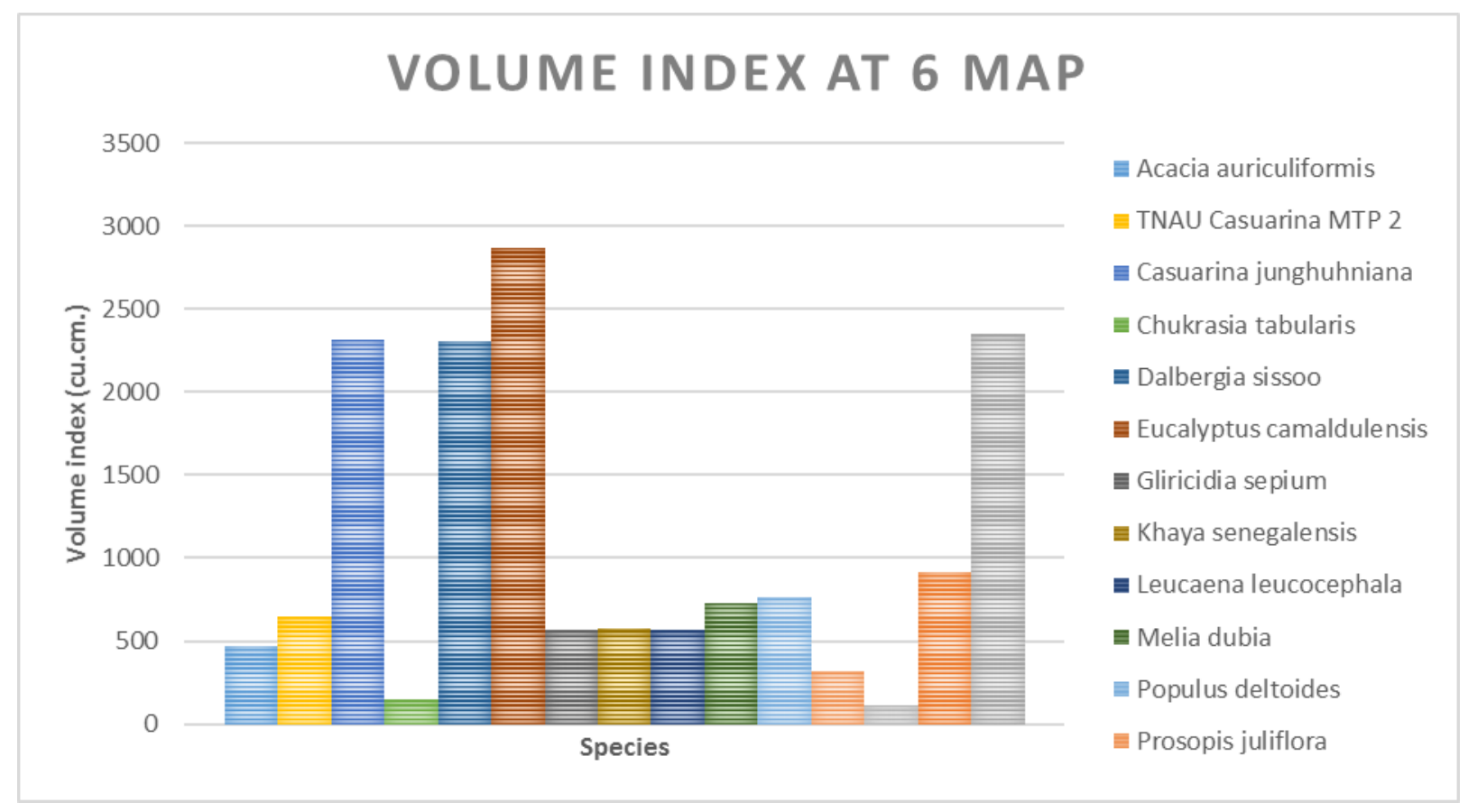




\section{Volume index}

The species differed significantly due to volume over four growth periods. At 2 MAP, Eucalyptus camaldulensis $\left(1052.62 \mathrm{~cm}^{3}\right)$ followed by Casuarina junghuhniana (682.75 $\left.\mathrm{cm}^{3}\right)$ and Cassia siamea $\left(327.87 \mathrm{~cm}^{3}\right)$ registered significantly higher volume compared to the general mean $\left(215.36 \mathrm{~cm}^{3}\right)$. At 4 MAP, Eucalyptus camaldulensis $\left(1838.42 \mathrm{~cm}^{3}\right), \quad$ Casuarina junghuhniana $\left(1424.85 \mathrm{~cm}^{3}\right)$ and Cassia siamea (1091.46 $\left.\mathrm{cm}^{3}\right)$ followed by Dalbergia sissoo $(860.98$ $\mathrm{cm}^{3}$ ) showed significant variations compared to the general mean $\left(517.56 \mathrm{~cm}^{3}\right)$.

At 6 MAP, Eucalyptus camaldulensis $\left(2865.34 \mathrm{~cm}^{3}\right)$, Cassia siamea $\left(2353.72 \mathrm{~cm}^{3}\right)$, Casuarina junghuhniana $\left(2318.06 \mathrm{~cm}^{3}\right)$ and Dalbergia sissoo $\left(2305.53 \mathrm{~cm}^{3}\right)$ had proved significantly higher compared to the general mean $\left(1042.83 \mathrm{~cm}^{3}\right)$.

Considering volume at all growth periods, Eucalyptus camaldulensis had the effective volume growth attribute followed by Cassia siamea, Casuarina junghuhniana and Dalbergia sissoo consistently proved superior (Table 3).

Biomass species for energy production should be resistant to browsing preferably a nitrogen fixer with good coppicing ability (Harris et $a l ., 2011)$. These besides the species intended for energy production should be fast growing and should produce wood of calorific value. Such species need to survive under adverse abiotic conditions; perennial deep root plants or able to tolerant of poor soil, low rainfall and generally required low management inputs. Tree species with the potential of producing larger volumes of straight branches and trunks are recorded as important fuel sources for the local population (Pasiecznik et al., 2000). Woody biomass species used in common agro forestry systems with multipurpose utility can also play a vital role in energy conversion. The vital factors for trees as an energy source are biomass growth rate, calorific value, suitability of species to local climate, the competition of land for other uses and extend of local expertise (Coote, 2005).

Taking these factors into consideration 15 species of fast growing nature with coppicing ability and few of them with nitrogen fixing capacity was incorporated in the evaluation program. The evaluation of species has been done under field conditions for a period of six months.

Under field conditions, among 15 species studied viz., Dalbergia sissoo, Eucalyptus camaldulensis, Casuarina jhunghuhniana and Cassia siamea were proved superior in shoot length increment in different growth periods. The highest shoot length observed in Eucalyptus camaldulensis $(291.01 \mathrm{~cm})$ followed by Dalbergia sissoo $(278.12 \mathrm{~cm})$ from 0.5 MAP to 6 months after planting among the selected species. This was in line with Schubert and Whitesell (1985) findings where a total of 30 tree species, including 15 Eucalyptus species, were evaluated for higher biomass production. They found that Eucalyptus saligna, E. grandis, E. urophylla and E. robusta consistently outperformed the other species in height, diameter, and survival.

Considering basal diameter in the current study, three species viz., Cassia siamea, Casuarina junghuhniana and Eucalyptus camaldulensis had best growth potential followed by Dalbergia sissoo and Acrocarpus fraxinifolius. The results of this parameter was related with analysis of morphological attributes of 10 tree species by Lamers et al., (2006) for determination of their suitability at 0.5 MAP, 7 MAP and 19 MAP where the mean stem diameter of $P$. nigra increased 
consistently at different observation periods which thereby attest the finding of current study. By considering volume index viz., Eucalyptus camaldulensis, Casuarina junghuhniana and cassia siamea showed significant variations among the selected species.

The study was conducted to screen fifteen tree species for fuel wood utility based on the growth attributes viz., shoot length, basal diameter and volume Index. The species viz., Acacia auriculiformis, Acrocarpus fraxinifolius, Cassia siamea, TNAU Casuarina MTP 2, Casuarina junghuhniana, Chukrasia tabularis, Dalbergia sissoo, Eucalyptus camaldulensis, Gliricidia sepium, Khaya senegalensis, Leucaena leucocephala, Melia dubia, Populus deltoides, Prosopis juliflora and Thornless Prosopis are evaluated under field conditons. Among the species evaluated, Eucalyptus camaldulensis, Casuarina junghuhniana, Cassia siamea and Dalbergia sissoo showed higher performance in the growth attributes viz., Shoot length, Basal diameter and Volume index comparing all other species under study.

\section{Acknowledgement}

Acknowledgments are due to Department of Tree Breeding, Forest College and Research Institute, Tamil Nadu Agricultural University and Auromira Bioenergy funded scheme on "Promotion and Popularization of renewable energy in Tamil Nadu". Gratitude is expressed towards my guide and scientists for their kind and support.

\section{References}

Christopher, B.F., J.E. Campbell and D.B. Lobell. 2007. Biomass energy: the scale of the potential resource. Trends in Ecology and Evolution, 23(2).

Coote, H.C. 2005. The economics of forest plantations and on-farm planting as a rural income-generating activity in the UK and Sri Lanka. In: Proceedings of the international conference on the issues for sustainable use of biomass resources for energy. Held August 2005 at Colombo Sri Lanka.

Hall, D.O., F. Rosillo-Calle, R.H. Williams and J. Woods. 1993. Biomass for energy - Supply prospects. In: Renewable energy - Sources of fuels and electricity. Johansson, T.B., H. Kelly, A.K.N. Reddy and R.H. Williams (Eds.). Island Press, Washington D.C., U.S.A.

Harris, P.J.C, J.E. Wright and E.J. Trenchard. 2011. Potential for rainfed woody biomass production for energy conversion in drought and salinity affected areas of Northern India. J. Sci. Ind. Res., 70: 572-582.

Lamers, J.P.A., A. Khamzina and M. Worbes. 2006. The analysis of physiological and morphological attributes of ten tree species for early determination of their suitability to afforest degraded landscapes in the Aral Sea Basin of Uzbekistan. Forest Ecology and Environment, 221: 249-259.

Manavalan, A. 1990. Seedling vigour and bioproductivity in woody biomass species. Ph.D. Thesis, Madurai Kamaraj University, Madurai.

Panse, V.G. and P.V. Sukhatme. 1978. Statistical methods for agricultural workers. ICAR Publication, New Delhi

Pasiecznik, N.M., P. Felker, P.J.C. Harris, L.N. Harsh, G. Cruz, J.C. Tewari, K. Cadoret and L.J. Maldonado. 2000. The Prosopis juliflora - Prosopis pallida complex: A Monograph. Coventry: HDRA.

Ravindranath, N.H. and D.H. Oakley Hall. 1995. Biomass, energy and environment - A developing country perspective from India. Oxford University Press, 
Oxford.

Schubert, T.H and C.D. Whitesell. 1985. Species trail for biomass plantations in Hawaii: a first appraisal. United States Dept. of Agriculture. p. 176.

Sinha, C.S., P.V. Ramana and V. Joshi. 1994. Rural energy planning in India: Designing effective intervention strategies. Energy Policy, 22(5): 112115.

Snedecor, G. 1961. Statistical methods. Ed. 5. Iowa State Univ. Press, Ames. Iowa. p. 534

Tonn B.E. (2002). Distant futures and the environment. Futures 34: 117-132.

\section{How to cite this article:}

Thirumurugan, M., K.T. Parthiban, S. Umesh Kanna and Thirunirai Selvan, R. 2018. Screening of Tree Species for Dendro Biomass Utility through Biometric Characterization. Int.J.Curr.Microbiol.App.Sci. 7(02): 749-755. doi: https://doi.org/10.20546/ijcmas.2018.702.094 